\title{
Everyday Nationalism and Authoritarian Rule: A Case Study of North Korea
}

\author{
Alexander Dukalskis ${ }^{*}(\mathbb{D}$ and Junhyoung Lee \\ School of Politics and International Relations, University College Dublin, Dublin, Ireland \\ ${ }^{*}$ Corresponding author. Email: alexander.dukalskis@ucd.ie
}

\begin{abstract}
This article traces the evolution of "everyday nationalism" in North Korea and assesses its relationship to authoritarian resilience. It argues that coercion and the prospect of coercion play important roles in policing the contours of everyday nationalism. The state is able to infuse nationalism and authoritarian control into everyday life, but the "success" of its efforts has limits. This is due to social changes and the ways that material failures nurtured doubts about the legitimacy of the government among some citizens. It draws on data from North Korean state media, secondary historical literature, and 58 semi-structured interviews with North Koreans living in South Korea.
\end{abstract}

Keywords: everyday nationalism; authoritarianism; North Korea

\section{Introduction}

Since its inception, the North Korean state has devoted sustained attention to crafting the world view of its citizens such that they are loyal to, or at least do not oppose, the government. These efforts of course involve fervent propaganda and massive parades, but they also unfold at more quotidian levels. The state uses classrooms, morning meetings at work places, and military training sessions to keep the state's official messages in the minds of the population. The content of North Korea's messaging has not always been static, but elements of nationalism have remained a common feature of North Korea's official public sphere for decades.

This article traces the evolution of "everyday nationalism" in North Korea and assesses its relationship with authoritarian resilience. It argues that censorship, coercion, and the prospect of coercion play important roles in blurring the lines between official nationalism and everyday nationalism. While people have private doubts or complaints about the government or its selfappointed position as a representative of the Korean nation, a well-developed alternative discourse has not emerged because the state exerts significant control over the public sphere even at the quotidian level of everyday conversation. Oftentimes North Koreans, and citizens of authoritarian states more generally, do not necessarily endorse the state's official nationalism formula, nor do they necessarily challenge it. However, some citizens have serious doubts about the legitimacy of the government and those doubts are nurtured by its material failures as well as ongoing social changes in North Korea.

Drawing on data from North Korean state media, secondary historical literature, and 58 semistructured interviews with North Koreans living in South Korea, the article aims to contribute in two ways. First, in line with this special issue, it elaborates on how everyday nationalism can contribute to or undermine authoritarian rule. Choosing an extreme case like North Korea allows for mechanisms of influence to be revealed most clearly. Second, the article aims to contribute to the 
growing literature on authoritarian legitimation, in particular by exploring how repression interacts with state legitimation claims. This relationship is a difficult one to unpack (Gerscewhski 2013) and doing so entails research that is able to analyze processes at the everyday level.

\section{Everyday Nationalism and Autocratic Legitimation}

Scholars attempting to understand authoritarian resilience often emphasize institutional configurations that help authoritarian elites manage and share power (Art 2012). Repression and keeping the military loyal constitutes another prevalent explanation for authoritarian persistence (Bellin 2012). Yet, long lasting authoritarian rule is more difficult without at least some degree of legitimacy in the eyes of the population. For this reason, some point to the "three pillars" of authoritarian stability as consisting of legitimation, repression, and co-optation (Gerschewski 2013; Maerz 2018a).

Recently scholars have begun in earnest to analyze the legitimation formulas of contemporary authoritarian states, including in case studies (Bray et al. 2019; Maerz 2018b; Morgenbesser 2017), cross-national analysis (Kailitz and Stockemer 2017; Dukalskis and Patane 2019), and conceptual essays (Gerschewski 2018; Dukalskis and Gerschewski 2017; van Haldenwang 2017). If there are indeed three "pillars" of autocratic stability-repression, co-optation, and legitimation-then understanding the legitimation claims of autocratic regimes is a useful and important endeavor.

A distinction can be made between legitimation, or the claims that an autocracy makes, and legitimacy, or the extent or depth of belief in those claims among the citizenry (Grauvogel and von Soest 2014; Dukalskis and Gerschewski 2017). In contexts of censorship and state control of the public sphere it is difficult to draw a clear line between acceptance or rejection of a regime's legitimacy claims (Truex and Tavana 2019; Gerschewski 2018). Indeed, at times belief might be beside the point as the autocratic state aims to shape citizens' sense of political possibilities rather than necessarily cultivate their specific support for the regime (Dukalskis 2017; Kuran 1997; Wedeen 1999). In this sense, legitimation can contribute to habituation or inertia that sustains the government by virtue of not opposing it (Connor 2003, 38-39). Nevertheless, evidence suggests that it matters for autocratic resilience and for specific policy outcomes how an autocratic regime legitimates its rule (Kailitz and Stockemer 2017; Grauvogel and von Soest 2014).

Against this backdrop, it is useful to consider how "everyday nationalism" can sustain or undermine authoritarian rule. Goode and Stroup (2015) provide a key theoretical and methodological text on this question. Drawing on Fox and Miller-Idriss (2008) they understand everyday nationalism as a set of practices that reify the nation, namely, talking, performing, choosing, and consuming. In cases of highly regulated authoritarian rule, these practices may be heavily controlled by the state with little public deviation from the official script, while in other cases citizens may be able to subtly subvert the nationalistic grounds of authoritarian rule through such practices. Goode and Stroup $(2015,726)$ posit that a variety of "behaviors and orientations" in the everyday sphere can contribute to authoritarian resilience, such as:

rejection of individual autonomy or displacement of subjectivity in politics; political delegation or inaction; rejection of civil society and the free press; rejection or vilification of political opposition or political alternatives to the incumbent regime; depoliticization or hollowing out of national and subnational governance; toleration of corruption; politicization of justice, or the diminution of social and political rights.

A distinction is commonly drawn between "everyday nationalism" and "banal nationalism." While the latter consists of the ways in which the state attempts to infuse official nationalistic symbols and practices into everyday life (Billig 1995), everyday nationalism has more to do with how citizens understand and appropriate those efforts. Citizens "consume" nationalistic messages and symbols in various ways that may or may not align with the state's vision (Fox and Miller-Idriss 2008). In highly repressive contexts where the state mandates its version of banal nationalism, such as in 
North Korea, it is difficult to disentangle it from everyday nationalism with reliable precision. The North Korean context also blurs Connor's (2003,26-28) distinctions between regime, government, and state legitimacy. North Korea's official legitimation discourse aims to meld them together so that, for example, opposition to the Kim family (regime) is tantamount to opposition to North Korea (the state).

To observe everyday nationalism, the nonofficial "bottom up" type of nationalism, in a place like North Korea, one has to look for interactions in which the state's coercive apparatus is not present. An indicator that official/banal nationalism has been effective as a legitimation device is if practices of everyday nationalism cohere with the state's preferred interpretations. Even here, however, given North Korea's well-developed surveillance system, it is difficult to draw a clear bright line between "banal" and "everyday" nationalism unless it is obvious that the latter is subversive. Indeed, the state strives to dissolve the distinction such that the "banal" (official) becomes taken for granted in the "everyday" (nonofficial). This raises the possibility that loyal expressions of everyday nationalism are simply preference falsification, or dissimulating one's true beliefs for fear of coercion (Kuran 1997). This possibility can never be completely discounted in a system like North Korea's, however if we can learn about citizen interactions and behaviors when the prospect of coercion or surveillance is lower, then we can have more confidence that preference falsification is not driving observations. North Korea already features pockets of "hidden transcripts" that challenge official narratives (Joo 2014), so expressions of everyday nationalism when coercion appears less certain are not coterminous with preference falsification.

How more specifically might the state successfully infuse its version of nationalism in everyday practices to bolster authoritarian resilience? There are at least two ways. First, a regulated, imposed nationalism as a legitimation device can shape everyday interactions in party-state venues that then bleed out into the everyday sphere. Behavioral expectations in schools, universities, military units, workplaces (at least in socialist regimes), and so on, are regulated by the imposition of nationalism. These institutions are key drivers of socializing citizens into behavioral norms and publicly acceptable beliefs, which can then shape their interaction and demands with the government (Distelhorst and $\mathrm{Fu}$ 2019). If citizens come to accept state-imposed legitimation messages even when they are not in official spaces or being "watched" by the state then they are less likely to question the government and more likely to shape their demands in line with government legitimation formulas. However even if they remain doubtful they are still less likely to publicly oppose the legitimation narrative if there are consequences for doing so, such as being identified as subversive by the surveillance apparatus. In "quiet times" when there is not a pressing necessity to rally around the ruling elite, nationalist practices can help reify solidarity and ideational hegemony (Goode 2012).

Second, the successful infusion of banal nationalism into everyday life provides a mobilizational reserve that can be called upon to "rally around the flag." In the face of real or perceived external threat, the state may benefit from whipping up nationalist sentiment. However, it is difficult to generate this out of nowhere, so if citizens are imbued with a state-imposed nationalism already, then it becomes easier to ratchet up domestic displays of nationalism when necessary. Everyday interactions beyond the reach of the state that reify the state's rally-around-the-flag message increase its resonance.

To study the contribution of banal nationalism to authoritarian resilience, and the potential for everyday nationalism to challenge it, Goode and Stroup (2015, 726-730), propose a three-step approach. First, the researcher should map the nationalist legitimation claims of the government and trace the ways they are infused in everyday life to influence citizens' talking, performing, choosing, and consuming. This is, in other words, the "banal nationalism" efforts by the state. The main data sources here are state messages and symbols. Second, the researcher should examine how these messages and state formulations manifest themselves in everyday practices of citizens. This moves us into the "everyday nationalism" realm of analysis. To do so the authors recommend ethnographic work, although they acknowledge its limitations and practical drawbacks in terms of 
comparison and generalizability. Third and finally comes verification, which involves crosschecking one's understandings against other sources, such as focus groups or experiments. Triangulation of this sort is necessary to ensure that findings are not idiosyncratic or biased. The remainder of this study follows the basic contours of this three-step methodological approach.

\section{Data}

As is often mentioned in the North Korean context, reliable data is difficult to obtain. The government is secretive at the upper echelons and does not allow researchers to access North Koreans for interviews, surveys, or other observational methods. Researchers therefore have to draw on other sources of data. This article will primarily use three sources to validate its arguments. First, it will rely on secondary historical texts. Historians and anthropologists of North Korea have analyzed archives from North Korea's former communist allies, documents captured by the United States during the Korean War, and visual propaganda and films to better understand the country's official discourse.

Second, the article will present descriptive statistics on two dimensions of North Korea's postCold War era propaganda. More details will be explained below, but the article uses two types of frequency counts in state media. It presents data on the locations of visits by North Korean elites to domestic sites as reported in state media as well as annual frequency of reference of key militaristic, nationalist, and communist terms in state media. These counts give us a "big picture" view of one aspect of North Korea's legitimation messaging.

Third, for more recent time periods and for more granular "everyday" data, the article supplements its analysis with data from 58 semi-structured interviews conducted by one of the authors over the course of seven years. Specifically, 25 interviews were conducted in September and October 2011, ten in June of 2012, and 23 in July and August of 2017. The interviews were with North Koreans who had left their country and were residing in the Seoul area. Interviewing defectors incurs challenges (Song and Denney 2019). They do not constitute a representative sample of North Korean society because they have chosen to leave. This means that their opinions about politics are systematically biased. To mitigate this issue, interviews focused on behaviors and processes that can be externally validated rather than on political opinions or private thoughts. This should alleviate major concerns that interviewee responses are tainted by the re-education process that North Koreans undergo when they first arrive in South Korea. ${ }^{1}$ Interviews can be crossreferenced against other published analyses of defector interviews (Joo 2010; Joo 2014; Fahy 2015), including those that gathered data with respondents in China instead of South Korea (Haggard and Noland 2011) to ensure that any idiosyncratic stories are not represented as commonplace and to alleviate concerns about influence stemming from South Korean acculturation.

In a semi-structured interview, the researcher has a set of topics she or he would like to cover but the freedom to pursue lines of inquiry as they come up in conversation (Mason 2002). The first set of interviews, those in 2011 and 2012, focused on the ways in which the state controlled the public sphere with its imagery and propaganda. The second set, those in 2017, focused on politics in everyday life in North Korea.

As noted previously, studying everyday nationalism in North Korea faces numerous constraints due to a lack of access, but perhaps just as importantly because repression and surveillance blurs the lines between banal and everyday nationalism. Nevertheless, to "observe" everyday nationalism in our interview sample, we took two approaches. First, as noted above, we focused on interactions between citizens as opposed to political opinions. This allows us to see people "talking" with and about the nation (Fox and Miller-Idriss 2008) even if we cannot directly observe them via ethnographic work. Second, we paid particular attention to interactions in which the state's repressive or surveillance system was not present. This gives us a better chance to see people "talking" and/or "consuming" the nation (Fox and Miller-Idriss 2008) in a less fettered way than if they were in an official setting and felt compelled to adhere to the state's mandated perspectives. None of the interactions or activities rose to the level of Connor's $(2003,27)$ overt challenges to 
political legitimacy (revolution, secession movements), except perhaps leaving the country all together. However, with interview methods we can assess the extent to which nationalism may help shape the worldview of citizens so as to induce a passive or implicit acquiesce to the state's legitimation claims (Connor 2003, 38-39).

\section{The Early Years: National Communism}

Japan colonized the entire Korean peninsula for decades until 1945, during which time Tokyo imposed a rigid system of social control backed by a large coercive presence. The colonial authorities took an assimilationist strategy in Korea, which entailed suppressing practices of Korean nationhood and replacing them with loyal expressions to Japan. Korean communist and nationalist movements during this period therefore had to assert Korean independence and identity amid a repressive and ideologically ambitious colonial regime (Rausch 2016). Upon liberation, the northern half of the peninsula came under Soviet control, and combined with indigenous communist movements, North Korea underwent a communist revolution and consolidation between 1945 and 1950. People's committees were organized around the country and in 1948 North Korea declared its independent statehood.

The revolution was characterized by an emphasis not only on building state structures but also by efforts to change the character of everyday life and instill new beliefs in the population. Between 1945 and 1950, "social relationships, culture and the arts, and everyday life in North Korea were the targets of intense transformative energies" (Armstrong 2003, 7; Kim 2013, 21). The new authorities committed significant budget outlays to disseminate propaganda, and the period saw mobile cinema units, photo and art exhibits, a new education system, and the emergence of a cult of personality surrounding Kim Il Sung (Armstrong 2003; Kim 2013). The aim was to craft newly conscious citizens for a new post-colonial socialist reality. In Kim's $(2013,14)$ words, "everyday life became at once the primary site of political struggle and the single most important arena for experiencing the revolution in progress."

In this new reality, Korean nationalism was to play a central role. ${ }^{2}$ North Korean and South Korean leaders do not agree on much, but even in these early days they shared similar views of the Korean nation. According to Shin $(2006,5)$, "while in contention for national legitimacy and representation, they did not dispute the ethnic homogeneity of the Korean nation, which they agreed spanned thousands of years and was based on a single bloodline." While North Korea was organized along Marxist-Leninist lines, even in these early days nationalism played a prominent role in legitimating the new regime (Scalapino and Lee 1972, 870-873). Throughout the 1950s and 1960s Kim Il Sung stressed the importance of Korea charting its own course within the parameters of communism (Shin 2006, 87). Juche, the state's official ideology, is a manifestation of this national communism insofar as it posits a Korea-centric view of the world and stresses the need to keep the national collective at the forefront of one's thoughts and actions (Cheong 1999). The imposition of Juche also entails everyday nationalist features to entrench nationhood in the practices of the population, such as selectively utilizing traditional culture, styles of dress, and established social morals and customs (Cha 2012).

During and after the revolution, there was more than just propagation of nationalism and new ideas, however, and the state during this period built a formidable surveillance and coercion system to control society. Stalinist and Maoist tactics of confession and self-criticism were implemented to police the bounds of public thought and behavior. Spying and social control were pervasive and police forces could censure deviations. The system of social control was meant to create new identities in the minds of North Koreans. Returning to the theoretical discussion above, one can posit that the aim was to transform the "banal" into "everyday:"

In the North Korean surveillance regime, social discipline was ideally not something to be imposed by outside regulation and coercion. Discipline was to be internalized through selfexamination and reform at the individual level, and 'thought struggle' leading to 'thought unification' at the collective level. (Armstrong 2003, 211) 
Indeed, after the revolution and the Korean War, the state continued to extend its reach into society and implement control mechanisms that would regulate everyday life. Ideology and ideological indoctrination efforts remained central. As Lankov $(2016,226)$ puts it: "the amount of ideological indoctrination was all but unprecedented even by the remarkably high standards of the socialist bloc." The emphasis on ideology was underpinned by surveillance and repression. In the "Collective Guidance Campaign" of 1958-1959, party cadres from Pyongyang were to go to every locality to work with local party cadres whose loyalty had been assured in order to determine the devotion of the people. Interrogations were conducted in schools, farms, factories, and offices; inquiries about family history were made, and individuals were to tell their life histories to the cadres so that the population could be grouped into categories according to their perceived loyalty (Scalapino and Lee 1972, 832-835).

The repression and emphasis on transforming the ideological consciousness of the masses has continued throughout North Korean history. Propaganda, surveillance, and the prospect of punishment for deviating from the official line combine to bolster authoritarian rule by deterring collective challenges. The regulation of everyday life and restructuring of social relationships so that they are filtered through the party-state aims "to prevent people from developing relationships and networks of trust that can be used as the basis for mobilized political opposition" (Byman and Lind 2010, 48).

The cult of personality around the Kim family as an embodiment of the nation remains a key basis for the government's legitimation. Weekend study sessions for members of mass organizations and party members mean that free time is regulated by the state and geared toward the national community. The sessions are overseen by the Ministry of People's Security and the content includes advocacy of the Suryong [leader] system, achievements of Kim Il Sung and Kim Jong Il, and propaganda of party policies. Political programs like meeting for self-criticism or seminars by the local unit of Ministry of People's Security function to reify social control (Jeon 2003).

The surveillance system remains strong despite a deterioration of state capacity in the 1990s. Society is organized into inminban, which are groups of about 40 families with one person appointed to head the group. The person is responsible for organizing the group for common projects, solving minor disputes, disseminating information, and reporting to the security apparatus when necessary. The panoptic-like system helps ensure that grumbles, complaints, or petty transgressions do not coalesce into collective challenges to the government.

As the Cold War wound down, North Korea's legitimation formula continued to consist of a form of national communism. As with other forms of national communist systems which emphasized their country's creative application of communism to local contexts, the formula can be understood in terms of whether the government put more weight on the nationalist side or the communist side of the scale. Until the collapse of Soviet communism, North Korea retained its national communism more or less unchanged (Dukalskis and Gerschewski 2018).

However, after the collapse, the North Korean state heavily leaned on nationalism in an attempt to delineate itself from communist experiments elsewhere that had run their course. As Chen and Lee $(2007,470)$ put it, "the demise of the communist bloc greatly elevated the ideological role of nationalism in North Korea, as the Kim regime desperately tried to distinguish itself from the East European and Soviet communist systems." Indeed, the emphasis was so strong that Shin $(2006,95)$ argues that North Korea's "primary ideology" was nationalism, not socialism or communism.

\section{From National Communism to Militarist Nationalism}

The 1990s were not easy on North Korea. The only leader it had ever known, Kim Il Sung, died in 1994. Most of the world's communist regimes collapsed while archrival South Korea democratized and developed rapidly. Most importantly, a combination of poor economic management and natural disasters saw a famine kill several hundred thousand people in the middle of the decade (Haggard and Noland 2007). 
Amid these developments, Kim Jong Il turned to the military to reinvigorate both state infrastructure and its foundation for legitimacy. ${ }^{3}$ This is a manifestation of the broader tendency for the North Korean state to evolve in response to pressing challenges (McEachern 2018). The militarization of North Korean society has roots in the 1960s and the campaign of "arming the whole people." As Kim Il Sung sought security amid a changing communist world, strengthening self-defense capabilities held understandable appeal to solidify national/regime security (Smith 2015, 136-163).

Kim Jong Il reinvigorated militarization by articulating a policy of Songun, or "military first politics" (Suh 2002). The policy was made official in 1997. It elevated the military as an institution, prioritized its needs for the purposes of budget allocation, and enhanced its status as a protector and embodiment of the state (Denney et al. 2016). Kim Jong Il likely emphasized Songun because North Korea's crippling state weakness during and following the famine prompted him to turn to the one institution that he thought could solidify the regime. The Korean Worker's Party was unable to avert disaster in the early- to mid-1990s and Kim Jong Il was apparently persuaded that the military could restore order and revive the country (Woo 2014).

The strategy was to valorize the military as the vanguard of the Korean revolution, which, as Kwon and Chung $(2012,71)$ note, "reversed the hierarchical relationship between the party and the army in conventional socialist state politics." The new policy was widely seen as empowering the Korean People's Army relative to the Korean Worker's Party, although how far this went in reality is still debated (Woo 2014). Jung (2004) argues that the policy entailed letting the military lead in terms of ideology and domestic political structures, but that it did not completely eclipse the party, much less the Kim family. Some argue that "the military assumed executive authority over the political sphere" (Smith 2015, 235; Denney et al. 2016) while others point to the limits of military power and the regime's successful coup-proofing mechanisms (Woo 2016; Byman and Lind 2010). Regardless, the state's legitimation messages emphasized the military as the leading force of the revolution (Armstrong 2005, 392).

The turn toward militaristic nationalism was reflected in the legitimation messages that the government disseminated to the population. The military was perhaps better able to represent the "nation" than internationalist communist discourse, which was on the decline globally at the time. The prominence accorded to the military increased markedly in official public discourse. Two sources of data substantiate this claim. First, data on the frequency of individual elite visits to military installations as reported in official media shows increased prominence accorded to military sites during this period. The North Korean official media often reports on inspection visits by elites. An individual or a set of leaders may visit a factory, farm, or military base, for example, to highlight the success of that venture. Previous research has used this data by analyzing who makes such visits (Ishiyama 2014). However, for the purposes of this study, we examine the destination of the visit rather than the identities of the persons making the visit. Our logic is that the destination provides a public signal of government priority. If party elites, for example, visit a military installation it shows that party officials feel obliged to show fealty to the military and/or that that military installation is the subject of financial or political investment. The more military installations are visited and publicly reported, the more the government is prioritizing the military as a foundation for legitimacy.

Figure 1 shows the percentage of elite individuals visiting military sector destinations (army bases) as a percentage of elite visits to destinations in all sectors (economic, art/culture, political). Data is drawn from the Leadership Tracker tool of NKNews.org, which lists all visits of elites as reported in state media. In total there are 18,177 observations of which 6,258 (or 34.4\%) were in the military sector. There is considerable variation by year, but 1997, the first official year of Songun, is the highest year with $79.4 \%$ of all visits being to military destinations. The years surrounding 1997 are also very high, as are the years during which North Korea was involved in the Six-Party Talks over its nuclear program. It is clear that upon initially taking power in the mid-1990s the Kim Jong Il administration emphasized the military in its public reporting of official visits. 


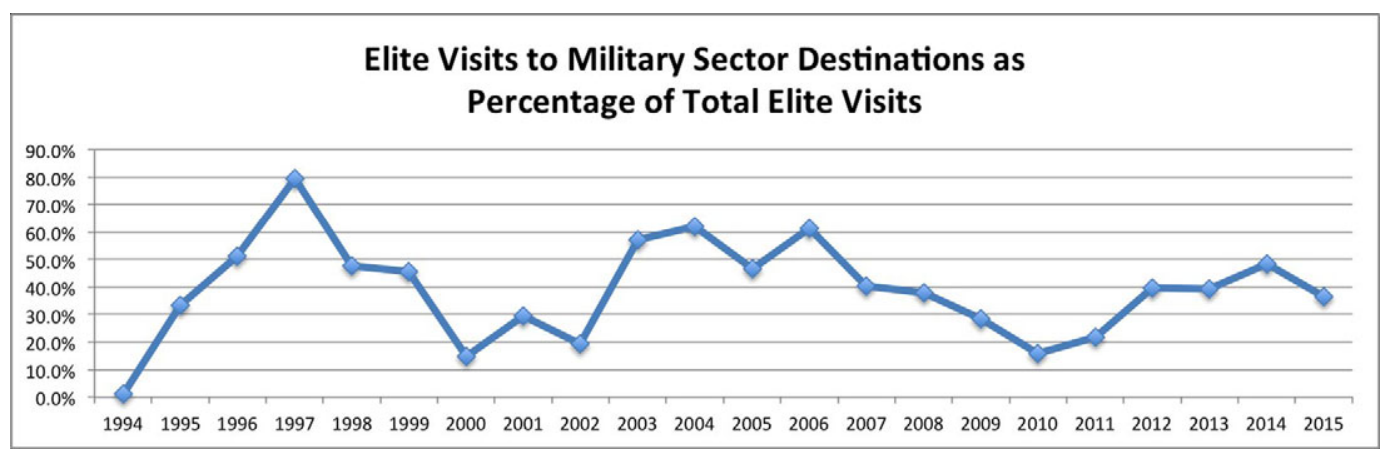

Figure 1. Elite Visits to Military Sector Destinations, 1994-2015.

Another indicator of how much weight the government accorded to the military in its official legitimation formula can be taken from how much the propaganda apparatus talks about the military. We attempt to capture this by analyzing over 123,000 state media articles from 1996 to 2016 accessed via the KCNA Watch tool of NKNews.org. For each year we conducted a frequency count of the number of articles mentioning military-related terms such as "armed forces," "military," "army," "defense/defence," "Songun," "weapon(s)," "war," and "nuclear." To generate an annual frequency count, we divided the number of times these terms appeared by the total number of articles in the database for that year and multiplied that number by 100 . These frequency counts can be taken as an additional piece of evidence to assess the legitimation emphasis accorded to the military for a given year. The results can be seen in Table 1 . The frequencies ranged from 2013, when military terms were mentioned 11 times for every 100 articles, to the year 2000, during which military terms were mentioned only 5.3 times per 100 articles.

We can extend this frequency analysis of military terms by comparing their prevalence to those of nationalist and communist terms in North Korea's media. This grouping of terms follows analysis by Dukalskis and Gerschewski (2018) that coded and analyzed communist and nationalist terms in four communist states based on the Oxford Handbook of Political Ideologies. The coding of terms emphasizes the conceptual "core" of communism as the vanguard position of the party, state ownership of the means of production, centralized (but democratic) decision-making, and the belief that a centrally-planned economy is more just than a market-based one (Brown 2013). Nationalism can be seen as emphasizing a shared identity that is distinct from other identities, sovereignty, common culture, and self-determination with the aim of achieving prosperity (Vincent 2013). For this analysis, specific communist terms were "communism/ist," "socialism/ist," "solidarity," "revolution," "market(s)," "party," "worker(s)," while the specific nationalist terms used were "independent/independence," "juche," "development," "prosperity," "stability," "power(ful)."

Figure 2 reveals the declining emphasis on communist themes in North Korea during the Kim Jong Il era. Communist themes went from 8.8 mentions per 100 articles in 1996 to 2.25 in 2003. From 2001 to 2011, communist themes were never discussed more than 4 times per 100 articles. This is consistent with secondary literature that emphasized the extent to which North Korea increasingly based its legitimation claims on other sources, such as charisma, neo-Confucianism, and personalist rule (Kwon and Chung 2012). Nationalistic terms remained relatively even throughout the period, suggesting that the government viewed them as a companion to militaristic language rather than a competitor. Nationalistic discourse appeared to be kept at a relatively consistent volume so as to supplement other official ideologies. The military and nation were to a large extent fused during the Kim Jong Il period while communism declined markedly.

These data from North Korean state media provide a starting point, but Goode and Stroup's (2015) methodological suggestion is to move beyond the claims the state makes to investigate how official nationalism is infused in everyday life to sustain (or undermine) authoritarianism. 
Table 1. Frequency of Military Terms in Korea Central News Agency (KCNA).

\begin{tabular}{|c|c|c|c|}
\hline Year & Total & Articles in Year & Mentions per 100 Articles \\
\hline 1996 & 26 & 238 & 10.9 \\
\hline 1997 & 219 & 3978 & 5.5 \\
\hline 1998 & 247 & 3694 & 6.7 \\
\hline 1999 & 364 & 4937 & 7.4 \\
\hline 2000 & 239 & 4485 & 5.3 \\
\hline 2001 & 190 & 3372 & 5.6 \\
\hline 2002 & 350 & 4181 & 8.4 \\
\hline 2003 & 400 & 4803 & 8.3 \\
\hline 2004 & 386 & 5156 & 7.5 \\
\hline 2005 & 385 & 5354 & 7.2 \\
\hline 2006 & 513 & 5538 & 9.3 \\
\hline 2007 & 399 & 5843 & 6.8 \\
\hline 2008 & 372 & 6195 & 6.0 \\
\hline 2009 & 425 & 6569 & 6.5 \\
\hline 2010 & 510 & 7105 & 7.2 \\
\hline 2011 & 960 & 13311 & 7.2 \\
\hline 2012 & 879 & 11200 & 7.8 \\
\hline 2013 & 1050 & 9548 & 11.0 \\
\hline 2014 & 575 & 9137 & 6.3 \\
\hline 2015 & 580 & 8841 & 6.6 \\
\hline 2016 & 608 & 6477 & 9.4 \\
\hline
\end{tabular}

Conceptually, this takes us from analysis of state-driven or "banal" nationalism in the form of media mentions to "everyday" nationalism in the form of consumption and interpretation of those messages. Interviews with North Korean defectors from the time validate that in everyday life the military was fused with the (North) Korean nation during this period.

The government infused military valorization into its existing propaganda streams. A former poet, for example, recalls that during the 1990s he and his colleagues were asked to incorporate Songun into their works (Respondent 25, October 14, 2011). ${ }^{4}$ In recounting her daily routine as a military nurse, a respondent from North Hamgyeong Province reported that each weekday two hours were devoted to studying the works of Kim Il Sung and Kim Jong Il, including the importance of the military (Respondent 18, October 7, 2011). A former soldier likewise noted the heavy study duties for military personnel, but also hinted at the limits on official discourse becoming natural everyday discourse among friends or colleagues. The implication is that coercion helps police the public sphere in the hopes that state messages do not compete with alternative perspectives in everyday life:

My colleagues and I could never talk about the political education because it's not allowed. Also, it is not that interesting to talk about. There are other more interesting things to talk 


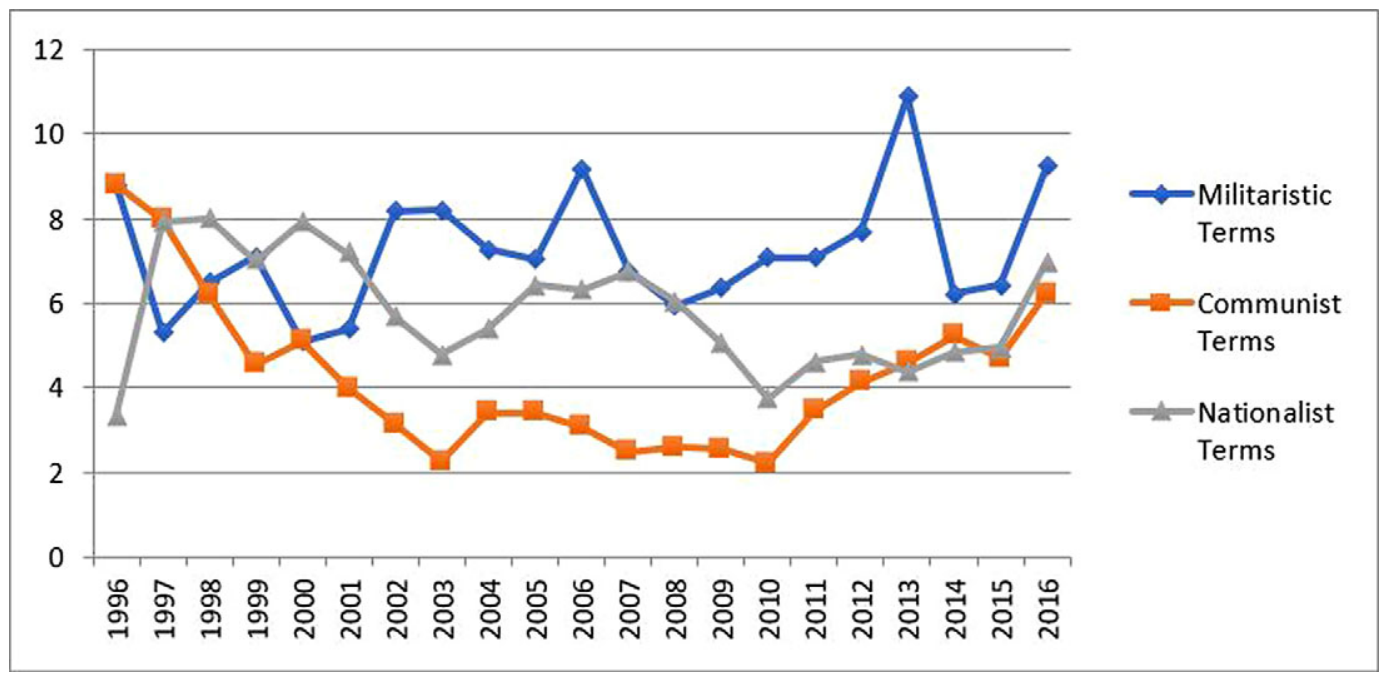

Figure 2. Mentions of communist, nationalist, and militaristic terms per 100 articles.

about. Since it's so much different from everyday life it's not something to really talk about. About the content, while I was in the army, Kim Jong Il was the leader. Even though there were a lot of details about the education, from what I remember the eventual goal of this whole education was to teach people that Kim Il Sung, through his anti-Japanese struggle, and the independence movement, that he was such a great supreme leader, how wonderful he is and how excellent he is. After being taught about all of this I was taught to be happy about it. It is thanks to Kim Jong Il that we were able to have such a happy and wealthy life. Because he is such an excellent leader, we as soldiers should risk our own lives to protect the country and our leader (Respondent 42, July 7, 2017).

In the civilian sphere, a former teacher from Wonson, Kangwon Province, recalls that during the Songun era, she and her colleagues were taught about the policy:

There was still the history of Kim Il Sung and Kim Jong Il but we would mention Songun. About why it was necessary. There is a slogan: 'at the end of a gun we can have peace.' We taught the students about why we are so concerned about military service and the army, because we have to protect ourselves (Respondent 24, October 14, 2011).

Students during the time period recall learning from their teachers about the importance of military first politics (Respondent 2, September 11, 2011; Respondent 27, June 10, 2012). For example, a former student in Pyongyang recalls the on-the-ground view of what political scientists would call the "rally around the flag" effect in which governments use an external threat in an attempt to induce loyalty. She recalls learning that "the United States is our enemy and we have to kill them [laughs]. And um, whenever we become relaxed, the United States will attack North Korea, so we should not relax or be absent-minded" (Respondent 21, October 8, 2011). A former student in Musan, on the Chinese border, recalls the mix of nationalism and militarism that characterized his education: "Since I was young... we were only taught that the government is good and that North Korea is the best in the world and that the Army policy is the best because America will attack us one day" (Respondent 27 , June 10,2012). The state's messages provide the atmosphere or context of everyday political life for authoritarian citizens. As a former student from North Hamgyeong Province put it in regard to Kim Il Sung: "there were lots of things saying Kim Il Sung is 
so admirable, and even after he died, there were still so many, so I just naturally remembered" (Respondent 1, September 11, 2011).

The prospect of coercion helped ensure that people were usually not willing to deviate from the official line. Further, word-of-mouth and rumors about coercion helped to ensure that the official line of everyday nationalism was often not breached in the everyday sphere even if people were inclined to do so. In what Stern and Hassid (2012) call "control parables" in the Chinese context, North Koreans often report hearing about or knowing someone (or knowing someone who knows someone) who has been caught while speaking negatively about the government. Such stories function to induce caution even when coercion is not certain. They help ensure that the state's messages and limits reach into the everyday sphere and everyday interactions when the state is not present. For example, a former student from the city of Cheongjin (Respondent 2, September 11, 2011; Respondent 42, July 8, 2017 tells a similar story) recounts in this exchange how during the military first era it was not possible to question the official narrative:

Q: Did you or your friends ever tell jokes about the government?

A: No.

Q: Even about the army or the local government representative?

A: No, I knew what would happen next [laughs]. That is for a person who is very brave.

Q: Did you ever hear anyone else saying these things?

A: A friend of a friend heard one. I heard about a person who was drunk and mentioned about Kim Jong Il's policies while he was drinking. Around them there was a person who was with the government. This guy was arrested for many years.

These examples illustrate that the state infused nationalism with militarism during the $1990 \mathrm{~s}$ and that everyday nationalism often closely mirrored the state's preferred messages, or at least did not challenge them very often. Data from state media show a "big picture" view, while interviews with North Koreans from a variety of backgrounds show how these messages spread into everyday life. The prospect of violent coercion helped the state maintain control, and rumor and control parables amplified the state's power in everyday interactions.

\section{Everyday Nationalism and Marketization}

However, amid the Songun period in the 1990s the relationship between state and society was being reconfigured due in large part to economic changes (Greitens 2019; Dukalskis 2016). During the famine of the 1990s, state capacity was critically undermined (Haggard and Noland 2007). The rationing system was unable to deliver food or other daily necessities for most citizens. In the midst of state breakdown, North Koreans turned to "self help" by engaging in illegal or quasi-legal market exchange or barter (Smith 2009; Joo 2010; Fahy 2015). This "grassroots capitalism" (Lankov and Kim 2008) or "marketization from below" (Haggard and Noland 2010a) added a new dimension to the state's ability to police its narrative.

The market spaces that emerged out of necessity in the 1990s provided a sphere of informational and social exchange that was less directly controlled by the state (Joo 2014). The possibility of surveillance in markets remained, but the power of surveillance was reduced relative to the days of citizens obtaining goods with ration tickets. Because party members were increasingly involved with market activities (Smith 2015, 220-226), markets were legitimized and government controls were treated as barriers to overcome rather than edicts to be obeyed. Survey evidence suggests cooperation among market participants to protect the interests of the market vis-à-vis the state (Haggard and Noland 2011, 114-115). Even if surveillance was not actually reduced, people acted as if it were, or at least as if the consequences for much rule-breaking constituted an acceptable risk. This space reveals the limits of the state's ability to inculcate its ideas fully. If the official discourse of Songun analyzed in the previous section was the banal nationalism of the period, the grassroots discourse of the markets reveals the everyday nationalism of the 1990s and beyond. In it, terms are 
reappropriated in ways that are sometimes at odds with the state's narratives as envisioned by Fox and Idriss (2008) but that do not overtly challenge the state.

The relationship between state and society changed, which influenced how official banal nationalism could be infused, received, and policed as the government attempted to reconstruct the North Korean state after the famine. The state media remains strong and continues to disseminate messages and dominate public discourse. However, state officials are now more susceptible to corruption than during the Kim Il Sung era (Haggard and Noland 2011; Lankov and Kim 2008; Scalapino and Lee 1972, 830), which means that citizens with illicit information products have more of a chance to bribe their way out of trouble. Furthermore, it is possible that the state's messages in the everyday sphere greet a more skeptical audience. As noted above, it is not advisable to generalize the attitudes of defectors to the entire population, but it is clear that there is at least enough skepticism about the government that a well-organized network helps people to defect and disseminate information and remittances back into North Korea despite government prohibitions. While this may not reach Connor's $(2003,28)$ standard of overt opposition to the regime/government/state, in the North Korean context evidence of skepticism and subtle reappropriation of official claims is significant.

Market activity began in earnest in the mid-1990s as the state was demonstrably unable to provide for much of the citizenry. A nurse recalls that medicines, for example, were not available via ordinary state channels, so patients had to go to the grey market to fill their prescriptions (Respondent 18, October 7, 2011). During this period, much market activity was illegal, so citizens were taking a risk in turning to the market. A respondent from North Hamgyeong Province remembers her experience going to the markets despite their official illegality:

A: Men could not usually go, but women could. It was illegal, but people did it and nobody was caught. People were starving.

Q: But at this time wasn't the government saying that people should not go to markets?

A: We did not have any other options. That was our own limitation. During rice planting, it was not possible to sell, but at other times it was OK. Everyone had to go rice planting. We did not get paid for that, but we had to go, so at night we went to the market.

Q: So earlier, you mentioned that you believed what the government said when you were in North Korea. But the government was saying not to go to markets, so I am wondering if you had any doubts about that?

A: I didn't doubt about the government, but I had to get by. Regular people just tried to live and did not think about the government's policies. They just had to make a living. My older sister lived in Cheongjin and at 4 a.m. there was a training for war preparation. We were trained in how to flight with a wooden shotgun or things. We complained about things with our family but we did not say anything to the government or to our bosses (Respondent 19, October 7, 2011).

The status of the markets during this period was technically illegal, but widely tolerated (Lankov 2013, 121). The government took the approach of toleration for lack of other options to feed the population. A respondent from Hamhung recalls the atmosphere in the mid-1990s: "they called it illegal but the government could not control it because it was really important for our living. So the government said it was illegal but did not really control it. But sometimes if they needed to, they would enforce some rules" (Respondent 29, June 11, 2012). A respondent from Cheongjin shares similar memories: "the government tried to stop people from selling things in the market, but they couldn't because people would buy them. At that time, black markets were very popular, they were everywhere" (Respondent 33, June 17, 2012). The markets were popular, and they preoccupied some people who were keen to make a better living amid the social changes around them: with friends "I would talk about selling or buying things-about the markets. When selling something how much I could make or how much I could spend" (Respondent 10, September 25, 2011). Most turned to the markets for lack of other options: 
At first people waited for the government to send out food but since the government did not do so people died-a lot of people died. I watched a lot of people die. People began to think that if we kept just waiting for the government to provide the food that we need we would all die. So we started to engage in the market and exchange necessary goods with each other. We saw that the factories and all the departments of the country were at a stop. Nothing was advancing anymore so we started to engage in the market. (Respondent 45, July 10, 2017)

Given that they existed slightly beyond the reach of the government's coercive apparatus, and that they were a symbol of the state's failure to provide, there was at least some potential for the black markets to become a space in which people could question the state's official narrative in everyday conversation. However, respondents still generally report not talking openly about politics in market spaces for fear of punishment. The markets were still thought of as "public" and therefore the usual norms of caution prevailed (Respondent 33, June 17, 2012). Even among vendors who were transporting potentially illegal goods, silence about politics was a protective mechanism. One person who was involved in transporting illicit goods between provinces explains her interactions with other members of her network:

I couldn't talk about the system with them a lot. In case we got caught in the process of transporting the goods, it would a disadvantage for me if one of my partners said that we talked about the system. We strictly had a wall between us so that it was just business. Even if we got caught, if I had had no conversation with them about the system, then we could excuse ourselves and say that we were just doing this to make a living and we didn't talk about the system at all. Even if everyone has this type of discontent toward the system and the government, it's not comfortable for us to talk with each other about how we feel about the system. It's dangerous for both sides if we get caught. It's sort of like showing respect to one another to not ask questions about how they felt about the system, it's kind of like trying to protect each other. Even if I didn't directly express discontent about the system with people, I could basically guess what a person is thinking or their basic attitude toward the government. Even if people don't say it directly they can use expressions or facial expressions or indirect wording. (Respondent 54, July 31, 2017).

Markets provide the opportunity for North Koreans to make a living more independent of the state. However, state agents are involved in the market, which further undermines their potential to directly challenge the narratives disseminated by the state. Police and inspection officers, for example, sometimes confiscate smuggled goods from China, Japan, or South Korea, and then sell them via their family members on the open market (Jeon 2003). Many market participants encounter the state in everyday interactions in the form of predatory officials to be bribed. Market vendors bribe police officers to avoid getting caught (Respondent 28, June 11, 2012). They develop mutually beneficial relationships with market inspectors over time in order to be alerted to potential crackdowns (Respondent 58, August 8, 2017; Respondent 46, July 11, 2017). In some cases, market participants would work closely with members of state institutions, as one respondent reports his experiences smuggling mushrooms to China using military trucks:

There are a lot of police stations in the mountains and when we would want to export these to China, we would have to work with people from the police or military. So, for example, if we wanted to pass these mushrooms to Chinese people, we would have to borrow someone's car from a military official and then drive it to somewhere and meet someone and give them money, and then borrow another car and drive to the Tumen River. (Respondent 26, June 10, 2012).

Some state agents clearly have a vested interest in these activities. One former police officer, for example, became a manager at an official export company. His position allowed him to smuggle goods in and out of China on the side, while his network of contacts from his former career as a 
police officer helped shield him from punishment (Respondent 49, July 13, 2017). While vulnerable to their superiors, state agents participating in the market still have more power than the citizens they are dealing with. While sometimes people would resist particularly unfair predation, it was difficult to organize collectively to oppose it since the state agent still had more power than the citizens (Respondent 46, June 11, 2017).

This reality limits the ability of the markets to function as a space from which overt challenges to the state's nationalism and authoritarianism can emerge. For some, it is clear that the market functions as a powerful symbol of the government's failure to provide for the population. Official state messages continue to posit the government as the protector of the Korean nation, and indeed under Kim Jong Un emphasis on economic development and prosperity have become more prominent (KCNA 2017). However, the legacy of the 1990s remains, and for some the memory of a subversive slogan during that time- “"The market place is our party [or new Worker's Party]"” (Kwon and Chung 2012, 169)-belies the state's claims. Some openly hope for a "war to break out" against the United States (Respondent 45, July 10, 2017; Respondent 58; August 8, 2017; see also Dukalskis and Joo forthcoming). This complaint has the advantage of being an officially-approved anti-American message, but citizens reinterpret it subtly to mean that they hope for an end to the regime. However, repressing private market activity risks making the market a space for political resistance (Haggard and Noland 2010b, 10), which suggests that the banal nationalism of the state will need to incorporate the market as part of its narrative in order to enduringly resonate with a large portion of the population.

\section{Conclusion}

Authoritarian politics influences everyday life in profound ways. By shaping the information environment of its citizens and reaching deeply into society via organizational and coercive mechanisms, the North Korean state has built a system designed to police everyday behavior. North Korea devotes significant effort to infusing everyday life with state-led nationalism while coercion and surveillance play important roles in policing adherence to the state's ideas. However, evidence from North Korea's markets suggests that the state is not entirely effective in securing legitimacy belief at the everyday level. Despite the penetration of the state's messages into everyday life, interactions in market spaces show that the North Korean people are not passive actors fully indoctrinated by ideology and cowed by the state apparatus but are active participants in constructing everyday nationalism.

There are at least three broad conclusions that can be drawn from this research, the first methodological, the second theoretical, and the third comparative. Methodologically, the study supports Goode and Stroup's (2015) suggestion to triangulate different forms of evidence about everyday nationalism. The article showed the value in analyzing messages disseminated by the state via its media as well as how citizens receive them. Doing so provides a well-rounded view of statecitizen interactions amid everyday life. While not as richly detailed as an ethnographic study, this approach bypasses the obstacle to ethnographic access presented by North Korea and triangulates data to reconstruct the texture of everyday nationalism.

Theoretically, the article reinforces the importance of looking below the high politics of authoritarian rule. Co-optation and coalition building at elite levels in authoritarian states are an undeniably important source of authoritarian resilience. However, they have their foundation in everyday authoritarianism (Dukalskis and Joo forthcoming). Authoritarian governments can co-opt major social changes such as marketization in North Korea in order to control the changes in everyday life that they bring but ignoring them is risky and repressing them may cause backlash.

Comparatively, there are compelling possibilities to apply this analysis to other contemporary authoritarian states. Doing so would help us better understand how and under what conditions legitimation claims result in legitimacy which in turn sustains authoritarian rule. A persistent problem in assessing the legitimacy of authoritarian states is the ability to accurately measure 
citizen's beliefs of the government (Dickson 2016; Truex and Tavana 2019). The approach developed here addresses this problem by adopting a detailed, fine-grained approach to observing how the state's claims play out in everyday life. Doing so is labor-intensive, but it yields data that can give us unparalleled insight into how authoritarianism and resistance to authoritarianism operate at the everyday level.

Acknowledgments. Dukalskis would like to thank interviewees who have shared their experiences with him over the years and helped to explain how North Korea works.

Financial Support. Portions of this research were funded by the Helen Kellogg Institute for International Studies (2011-12) and the Kroc Institute for International Peace Studies (2011), both at the University of Notre Dame, as well as the Royal Irish Academy (Charlemont Grant, 2018) and the Korea Foundation (Fellowship for Field Research 2017, ref. 1023000-2304).

Disclosure. Authors have nothing to disclose.

\section{Notes}

1 This contrasts with Demick (2009), who reports the retrospective inner states of her interviewees extensively.

2 It is worth noting that because of its emphasis on the Korean nation instead of just the state, the government's approach resonates more with nationalism than a nonethnic style of patriotism.

3 Portions of this section are adapted from and expand on the conference paper of Shin and Dukalskis, 2016.

4 Respondents are anonymized for their protection. Interviews are referenced by their respondent number and the date the interview was conducted in Month, Day, Year format. Portions of these interview samples are analyzed elsewhere in Dukalskis (2017), Dukalskis (2018), and Dukalskis and Joo (forthcoming).

\section{References}

Art, David. 2012. “What Do We Know About Authoritarianism After Ten Years?” Comparative Politics 44 (3): 351-373.

Armstrong, Charles K. 2005. "Familism, Socialism and Political Religion in North Korea." Totalitarian Movements and Political Religions 6 (3): 383-394.

Armstrong, Charles K. 2003 The North Korean Revolution, 1945-1950. Ithaca, NY: Cornell University Press.

Bellin, Eva. 2012. "Reconsidering the Robustness of Authoritarianism in the Middle East: Lessons from the Arab Spring." Comparative Politics 44 (2): 127-149.

Billig, Michael. 1995. Banal Nationalism. London: Sage.

Bray, Laura A., Thomas E. Shriver, and Alison E. Adams. 2019. "Framing Authoritarian Legitimacy: Elite Cohesion in the Aftermath of Popular Rebellion." Social Movement Studies 18 (6): 682-701.

Brown, Archie. 2013. "Communism." In The Oxford Handbook of Political Ideologies, edited by Michael Freeden, Lyman Tower Sargent and Marc Stears, 364-384. Oxford: Oxford University Press.

Byman, Daniel, and Jennifer Lind. 2010. "Pyongyang's Survival Strategy: Tools of Authoritarian Control in North Korea." International Security 35 (1): 44-74.

Cha, Nam Hee. 2012. "Juche Idea and Nationalism: Constancy and Variation of the Governing Ideology in North Korea." [In Korean.] Discourse 20115 (4): 109-140.

Chen, Cheng and Ji-Yong, Lee. 2007. "Making Sense of North Korea: "National Stalinism" in comparative-historical perspective." Communist and Post-Communist Studies 40 (4): 459-475.

Cheong, Seoung Chang. 1999. “Theoretical Structure and Characteristics of the Juche Ideology.” [In Korean.] North Korean Studies Review 3 (2): 251-273.

Connor, Walter. 2003. "Nationalism and Political Illegitimacy." In Ethnonationalism in the Contemporary World: Walter Connor and the Study of Nationalism, edited by Daniele Conversi, 42-68. New York: Routledge.

Demick, Barbara. 2009. Nothing to Envy: Ordinary Lives in North Korea. New York: Random House.

Denney, Stephen, Christopher Green, and Adam Cathcart. 2016. "Kim Jong Un and the Practice of Songun Politics." In Change and Continuity in North Korean Politics, edited by Adam Cathcart, Robert Winstanley-Chesters, and Christopher K. Green, 53-64. London: Routledge.

Dickson, Bruce. 2016. The Dictator's Dilemma: The Chinese Communist Party's Strategy for Survival. Oxford, UK: Oxford University Press. 
Distelhorst, Greg, and Diana Fu. 2019. "Performing Authoritarian Citizenship: Public Transcripts in China. Perspectives on Politics 17 (1): 106-121.

Dukalskis, Alexander. 2017. The Authoritarian Public Sphere: Legitimation and Autocratic Power in North Korea, Burma, and China. London: Routledge.

Dukalskis, Alexander. 2016. "North Korea's Shadow Economy: A Force for Authoritarian Resilience or Corrosion?" EuropeAsia Studies 68 (3): 487-507.

Dukalskis, Alexander, and Johannes Gerschewski. 2018. “Adapting or Freezing? Ideological Reactions of Communist Regimes to a Post-Communist World.” Government \& Opposition. Early view doi: https://doi.org/10.1017/gov.2018.40.

Dukalskis, Alexander, and Gerschewski, Johannes. 2017. "What Autocracies Say (and What Citizens Hear): Proposing Four Mechanisms of Autocratic Legitimation." Contemporary Politics 23 (3): 251-268.

Dukalskis, Alexander, and Hyung-min Joo. Forthcoming. "Everyday Authoritarianism \& Resistance in North Korea." EuropeAsia Studies.

Dukalskis, Alexander, and Christopher Patane. 2019. "Justifying Power: When Autocracies Talk About Themselves and Their Opponents." Contemporary Politics.

Fahy, Sandra. 2015. Marching Through Suffering: Loss and Survival in North Korea. New York: Columbia University Press.

Fox, John E., and Cynthia Miller-Idriss. 2008. "Everyday Nationhood.” Ethnicities 8 (4): 536-563.

Gerschewski, Johannes. 2018. “Legitimacy in Autocracies: Oxymoron or Essential Feature?” Perspectives on Politics 16 (3): $652-665$.

Gerschewski, Johannes. 2013. "The Three Pillars of Stability: Legitimation, Repression, and Co-optation in Autocratic Regimes." Democratization 20 (1): 13-38.

Goode, J. Paul. 2012. "Nationalism in Quiet Times: Ideational Power and Post-Soviet Hybrid Regimes." Problems of PostCommunism 59 (3): 6-16.

Goode, J. Paul, and David R. Stroup. 2015. “Everyday Nationalism: Constructivism for the Masses.” Social Science Quarterly 96 (3): 717-739.

Grauvogel, Julia, and Christian von Soest. 2014. "Claims to Legitimacy Count: Why Sanctions Fail to Instigate Democratization in Authoritarian Regimes.” European Journal of Political Research 53 (4): 635-653.

Greitens, Sheena Chestnut. 2019. "Explaining Economic Order in North Korea." In Korea and the World: New Frontiers in Korean Studies, edited by Gregg A. Brazinsky, 129-156. Lanham, MD: Rowman \& Littlefield.

Haggard, Stephen, and Marcus Noland. 2011. Witness to Transformation: Refugee Insights into North Korea. Washington, DC: Peterson Institute for International Economics.

Haggard, Stephan, and Marcus Noland. 2010a. "Reform from Below: Behavioral and Institutional Change in North Korea." Journal of Economic Behavior \& Organization 73 (2): 133-152.

Haggard, Stephan, and Marcus Noland. 2010b. The Winter of Their Discontent: Pyongyang Attacks the Market, Policy Brief PB10-1. Washington, DC: Peterson Institute for International Economics.

Haggard, Stephan, and Marcus Noland. 2007. Famine in North Korea: Markets, Aid and Reform. New York: Columbia University Press.

Ishiyama, John. 2014. "Assessing the Leadership Transition in North Korea: Using Network Analysis of Field Inspections, 1997-2012.” Communist and Post-Communist Studies 47 (2): 137-146.

Jeon, Hyun Jun. 2003. "A Study on the Social Control Organisation of North Korea; focusing on the Ministry of People's Security.” [In Korean.] Working Paper 03-44. Korea Institute for National Unification.

Joo, Hyung-Min. 2014. "Hidden Transcripts in Marketplaces: Politicized Discourses in the North Korean Shadow Economy." Pacific Review 27 (1): 49-71.

Joo, Hyung-Min. 2010. "Visualizing the Invisible Hands: The Shadow Economy in North Korea." Economy and Society 39 (1): $110-145$.

Jung, Sung Im. 2004. “Military-First Politics' and the Role of the Korean People’s Army in North Korea." [In Korean.] Journal of National Defense Studies 47 (1): 109-134.

Kailitz, Steffen, and Daniel Stockemer. 2017. "Regime Legitimation, Elite Cohesion and the Durability of Autocratic Regime Types.” International Political Science Review 38 (3): 332-348.

Kim, Suzy. 2013. Everyday Life in the North Korean Revolution, 1945-1950. Ithaca, NY: Cornell University Press.

Korean Central News Agency (KCNA). 2017. "Kim Jong Un Makes New Year Address," Korean Central News Agency, 1 January. Available at: http://www.kcna.kp/kcna.user.article.retrieveNewsViewInfoList.kcmsf;jsessionid=6B600B4DE118 BEAB1F55DF3D507EEC0B\#this. (Accessed March 13, 2019.)

Kuran, Timur. 1997. Private Truths, Public Lies: The Social Consequences of Preference Falsification. Cambridge, MA: Harvard University Press.

Kwon, Heonik, and Byung-Ho Chung. 2012. North Korea: Beyond Charismatic Politics. Lanham, MD: Rowman \& Littlefield Publishers.

Lankov, Andrei. 2016. “A Dynastic Polity in Economic Stagnation and Decline." In Routledge Handbook of Modern Korean History, edited by Michael J. Seth, 221-233. New York: Routledge.

Lankov, Andrei. 2013. The Real North Korea: Life and Politics in the Failed Stalinist Utopia. New York: Oxford University Press. 
Lankov, Andrei, and Seok-hyang Kim. 2008. "North Korean Market Vendors: The Rise of Grassroots Capitalists in a PostStalinist Society." Pacific Affairs 81 (1): 53-72.

Maerz, Seraphine F. 2018a. "The Many Faces of Authoritarian Persistence: A Set-Theory Perspective on the Survival Strategies of Authoritarian Regimes." Government \& Opposition 55 (1): 64-87.

Maerz, Seraphine F. 2018b. “Ma'naviyat in Uzbekistan: An Ideological Extraction from Its Soviet Past?” Journal of Political Ideologies 23 (2): 205-222.

Mason, Jennifer. 2002. Qualitative Researching. London: Sage Publications.

McEachern, Patrick. 2018. "Comparative Authoritarian Institutionalism, Regime Evolution, and Stability in North Korea," Asian Journal of Comparative Politics 3 (4): 367-385.

Morgenbesser, Lee. 2017. “The Autocratic Mandate: Elections, Legitimacy and Regime Stability in Singapore." The Pacific Review 30 (2): 205-231.

Rausch, Franklin. 2016. "Nationalist Movements Before 1945." In Routledge Handbook of Modern Korean History, edited by Michael J. Seth, 153-168. New York: Routledge.

Scalapino, Robert A., and Chong-Sik Lee. 1972. Communism in Korea, Volume 2: The Society. Berkeley: University of California Press.

Shin, Gi-Wook. 2006. Ethnic Nationalism in Korea: Genealogy, Politics, and Legacy. Stanford, CA: Stanford University Press.

Shin, Ji Hye, and Alexander Dukalskis. 2016. "Authoritarian Survival, Military Power, and Foreign Policy: A Case Study of North Korea.” Paper presented at the International Studies Association convention, Atlanta, Georgia, March 16-19.

Smith, Hazel. 2015. North Korea: Markets and Military Rule. Cambridge, UK: Cambridge University Press.

Smith, Hazel. 2009. "North Korea: Market Opportunity, Poverty and the Provinces.” New Political Economy 14 (2): $231-256$.

Song, Jay, and Steven Denney. 2019. "Studying North Korea through North Korean Migrants: Lessons from the Field." Critical Asian Studies 51 (3): 451-466.

Stern, Rachel E., and Jonathan Hassid. 2012. “Amplifying Silence: Uncertainty and Control Parables in Contemporary China." Comparative Political Studies 45 (10): 1230-1254.

Suh, Dae-Sook. 2002. "Military-First Politics of Kim Jong Il.” Asian Perspective 26 (3): 145-167.

Truex, Rory, and Daniel L. Tavana. 2019. "Implicit Attitudes toward an Authoritarian Regime.” Journal of Politics 81 (3): 1014-1027.

Vincent, Andrew. 2013. "Nationalism." In The Oxford Handbook of Political Ideologies, edited by Michael Freeden, Lyman Tower Sargent, and Marc Stears, 452-473. Oxford: Oxford University Press.

Von Haldenwang, Christian. 2017. “The Relevance of Legitimation: A New Framework for Analysis.” Contemporary Politics 23 (3): 269-286.

Wedeen, Lisa. 1999. Ambiguities of Domination: Politics, Rhetoric, and Symbols in Contemporary Syria. Chicago: University of Chicago Press.

Woo, Jonseok. 2016. "Songun Politics and the Political Weakness of the Military in North Korea: An Institutional Account." Problems of Post-Communism 63 (4): 253-262.

Woo, Jongseok. 2014. "Kim Jong Il's Military-First Politics and Beyond: Military Control Mechanisms and the Problem of Power Succession." Communist and Post-Communist Studies 47 (2): 117-125.

Cite this article: Dukalskis, A. and Lee, J. 2020. Everyday Nationalism and Authoritarian Rule: A Case Study of North Korea. Nationalities Papers 48: 1052-1068, doi:10.1017/nps.2019.99 